\title{
Plant management and biodiversity conservation in Náhuatl homegardens of the Tehuacán Valley, Mexico
}

\author{
Carolina Larios ${ }^{1}$, Alejandro Casas $^{1 *}$, Mariana Vallejo ${ }^{1}$, Ana Isabel Moreno-Calles ${ }^{2}$ and José Blancas ${ }^{1}$
}

\begin{abstract}
Background: The Tehuacán Valley is one of the areas of Mesoamerica with the oldest history of plant management. Homegardens are among the most ancient management systems that currently provide economic benefits to people and are reservoirs of native biodiversity. Previous studies estimated that $30 \%$ of the plant richness of homegardens of the region are native plant species from wild populations. We studied in Náhuatl communities the proportion of native plant species maintained in homegardens, hypothesizing to find a proportion similar to that estimated at regional level, mainly plant resources maintained for edible, medicinal and ornamental purposes.

Methods: We analysed the composition of plant species of homegardens and their similarity with surrounding Cloud Forest (CF), Tropical Rainforest (TRF), Tropical Dry forest (TDF), and Thorn-Scrub Forest (TSF). We determined density, frequency and biomass of plant species composing homegardens and forests through vegetation sampling of a total of 30 homegardens and nine plots of forests, and documented ethnobotanical information on use, management, and economic benefits from plants maintained in homegardens.

Results: A total of 281 plant species was recorded with 12 use categories, 115 ornamental, 92 edible, and 50 medicinal plant species. We recorded $49.8 \pm 23.2$ (average \pm S.D.) woody plant species (shrubs and trees) per homegarden. In total, 34\% species are native to the Tehuacán Valley and nearly $16 \%$ are components of the surrounding forests. A total of 176 species were cultivated through seeds, vegetative propagules or transplanted entire individual plants, 71 tolerated, and 23 enhanced. The highest species richness and diversity were recorded in homegardens from the CF zone (199 species), followed by those from the TRF (157) and those from the TDF (141) zones.
\end{abstract}

Conclusion: Homegardens provide a high diversity of resources for subsistence of local households and significantly contribute to conservation of native biodiversity. The highest diversity was recorded in homegardens where the neighbouring forests had the least diversity, suggesting that management of homegardens aims at compensating scarcity of naturally available plant resources. Cultivated species were markedly more abundant than plants under other management forms. Diversity harboured and management techniques make homegardens keystones in strategies for regional biodiversity conservation.

Keywords: Biodiversity conservation, Domestication, Homegardens, Náhuatl people, Plant management, Sustainable use, Tehuacán Valley

\footnotetext{
* Correspondence: acasas@cieco.unam.mx

${ }^{1}$ Centro de Investigaciones en Ecosistemas, UNAM, Antigua Carretera a

Pátzcuaro 8711, Col. San José de la Huerta Morelia, Michoacán 58190, México

Full list of author information is available at the end of the article
} 


\section{Background}

Homegardens are important agroforestry systems developed by numerous human cultures worldwide [1]. Characteristically located attached to peoples' houses, these systems are commonly formed by a variety of plant and animal species either wild and domesticated, whose composition and structure are continually transformed according to plans designed by humans that manage them [1-7]. These processes illustrate mechanisms of domestication operating at ecosystems and landscape levels $[8,9]$. Homegardens commonly are reservoirs of agrobiodiversity but also they may maintain native natural biodiversity $[6,8]$, including genetic diversity of species occurring wild in forests [10-12]. This is possible since local people that manage the system frequently carry to homegardens plants from the wild [13-18], which favours gene flow from wild and cultivated components $[8,9,12,17-19]$ and ecological processes similar to those occurring in the surrounding forests. All these aspects in theory confer to homegardens a high resilience capacity [1].

People that manage homegardens find in them multiple goods to satisfy their social, cultural and economic needs, mainly food, medicines, ornamental and spiritual wellbeing, fodder, fuel wood, and products that generate monetary incomes [13,20-22]. Several authors have documented that these systems are also areas where domestication is experimented and agricultural practices are commonly tested there before carrying out them into parcels in fields out of the villages $[6,9,12,15,17,23]$. Since homegardens are spaces of resources, management techniques, and human cultural processes these systems are considered as important reservoirs of biocultural heritage $[24,25]$.

The great variety of products provided by homegardens occurs in areas relatively small. According to Van der Wal and Bongers [26] homegardens in rural regions of Mexico may be 'small' (less than $1,000 \mathrm{~m}^{2}$ ), 'intermediate sized' $\left(1,000 \mathrm{~m}^{2}\right.$ to $2,000 \mathrm{~m}^{2}$ ), and 'large' (more than $2,000 \mathrm{~m}^{2}$ ), which indicates that such high diversity maintained in small areas necessarily involves strategies for optimizing usage of space and resources such as light, nutrients and water.

Several authors have questioned the capacity of traditional agricultural systems for reaching the challenges of productivity required for feeding the global society, suggesting that it is only through intensive industrialized systems that such purpose can be accomplished; however, it is real that the intensive industrialized systems have failed in numerous contexts and that their achievements have been accompanied with high environmental costs [27]. Therefore, looking for strategies for improving capacities of the traditional systems has become a new paradigm for constructing sustainable security systems of food and other goods for human life [28].
The purposes of increasing productivity has commonly promoted the simplification of traditional agroforestry systems, consequently leading to lose some of the principal attributes of sustainability [7,29]. One of the greatest challenges of the contemporary human societies is therefore how to achieve optimum productivity without losing diversity of components and functions of these systems. According to an increasing number of authors [5,27], productivity and sustainability are concealable properties of agroecosystems through agroecological principles. Documenting local management experiences, therefore, has become a primary source of empirical information for developing theory about such important principles. This is what our current study looks contributing for.

Different indigenous cultures in Mesoamerica have conserved traditional ecological knowledge and forms of natural resources management [21,24,25,30,31], which represent thousands of years of adaptation of human groups to particular surrounding environments and confer to them a high potential contribution for sustainable socio-ecological systems and biodiversity conservation $[32,33]$. However, traditional knowledge and techniques are currently endangered and in process of gradual disappearing throughout the World [24,25]. Promotion of modern techniques considered as having higher effectiveness and cultural prestige, migration, unemployment favouring abandonment of agricultural practices, bad governmental assistance policies, fragmentation of land tenure, among others are all factors influencing losing of traditional systems of resource management $[7,29,31]$.

The Tehuacán Valley is one of the arid zones with the highest biodiversity of the Americas [34]. Although few studies are still available on agroforestry systems of that region, it has been documented that these systems, among them homegardens, harbour high native biological diversity $[6,7,29]$, and could be key targets for policies of biodiversity conservation at regional level $[6,18]$. More studies are needed for constructing such a strategy; for instance, only one case study of homegardens [20] has been reported in the literature for the region. Natural resources managed in agroforestry systems in general and homegardens in particular could be targets for improving conditions of human life and for maintaining ecosystem services. Socio-ecological sustainability should include ecological, social and economic dimensions [35,36] and therefore, homegardens as systems complementing ecological functions and households wellbeing are important bases for designing socio-ecological sustainable ways of life [37]. An agroforestry system is more probably ecologically sustainable when allows biodiversity conservation and maintenance of water and soil, which in turn favours diversity of biotic interactions buffering changes in temperature and humidity, maintenance of nutrients cycling, efficient 
use of light and waste management determining wellbeing of people that manage them $[37,38]$.

Our study focused on determining composition of homegardens in Náhuatl rural communities, evaluating the capacity of these systems for conserving native biodiversity and their role in households' economy, but we particularly emphasized documenting the local management techniques since we value them as crucial human experience for explaining past processes and the current state of problems, as well as for designing future management strategies [17]. Previous studies in the region have identified general forms of plant management in agroforestry systems, such as tolerance, promotion, protection, and cultivation $[6,9,17,23,39]$. In homegardens, tolerated plants are those growing 'spontaneously' (not human mediated but by natural propagation means) and that people let standing deliberately since they obtain a benefit (direct use or service) or because presence of plants do not cause any damage. Plants promoted or enhanced are those tolerated, already occurring in homegardens, and that people deliberately propagate by sowing their seeds or planting their vegetative propagules or entire young plants with the purpose of increasing their availability. People also use to protect especially those tolerated plants that are particularly valuable; for instance, they may provide structures for appropriate growing, construct irrigation systems to benefit them, take actions for protecting plants against herbivores, or prune neighbouring plants to let sun light reaching the protected plants. Cultivation involves sowing or planting of plants that were not naturally in homegardens areas and that people bring to them from the wild or from other agricultural systems $[6,9,23]$.

Studies of traditional agricultural systems in tropical regions of the world provide important information for understanding ecological processes associated to sustainable management of natural resources [40]. Agroecology, according to Gliessman [40], is the application of concepts and principles of ecology for sustainably designing and managing agroecosystems; consequently, our study looks for understanding cultural and ecological principles connecting explicitly the value of ethnobiological approaches for understanding structure and functions of homegardens at local scale in order to identify bases for designing strategies of their sustainable management at both local and regional levels.

We studied homegardens managed by the Náhuatl people of communities at Coyomeapan, and Coxcatlán Puebla, in the Tehuacán Valley, analysing their capacity to maintain native species and their possible role in policies for biodiversity conservation and wellbeing of local people. We hypothesized that since native plant species are continually introduced to homegardens by people, plant diversity harboured in these systems would be proportional to the natural diversity existing in local forests, and also similar to the proportion of native plant species found in homegardens at regional level; we also expected that native species were mainly represented by components of the neighbouring natural vegetation within the territory of a village. We documented the benefits local people obtain from managing these systems, particularly those of the native species. In this respect we supposed that the primary aims directed to manage homegardens is easing access to edible, medicinal and ornamental plants, in this order. And finally, we documented plant management involved in homegardens, expecting higher frequency of tolerance and transplanting as found in other agroforestry systems of the communities studied. Our study aimed at: (1) inventorying plant species occurring in homegardens, their nomenclature, use and traditional management, (2) determining richness, abundance and diversity of plant species composing homegardens, and their role in maintaining native plant species, and (3) evaluating harvest, consumption and incomes obtained from homegardens' products and comparing the role of this system in people's subsistence and culture in different ecological conditions.

\section{Methods}

\section{Study area}

We studied homegardens from villages of the municipalities of Coyomeapan and Coxcatlán, located at the southeast of the state of Puebla in central Mexico (Figure 1). In the municipality of Coyomeapan we studied the communities of Coyomeapan at elevations averaging $2800 \mathrm{~m}$, Ahuatla at $2400 \mathrm{~m}$, Yohuajca at $2200 \mathrm{~m}$, Chimalhuaca at $1840 \mathrm{~m}$, and Aticpac at $1140 \mathrm{~m}$. In these communities the predominant vegetation is distributed in three main environmental zones as follows: (1) Cloud Forest Zone (CFZ) in Coyomeapan and Ahuatla, (2) Tropical Rainforest Zone (TRFZ) in Aticpac, and (3) Tropical Dry Forest Zone (TDFZ) in Chimalhuaca and Yohuajca. In addition, we included in our analysis information from homegardens of a Thorn-Scrub Forest Zone (TSFZ) previously studied by Blanckaert et al. [20] in the village of San Rafael, in the municipality of Coxcatlán, neighbouring to Coyomeapan at $1200 \mathrm{~m}$ of elevation; also, we considered the information from the natural vegetation surrounding this village and studied by Vivar [41]. People of the communities studied live based on agriculture practiced in traditional agroforestry systems in fields out of the villages $[7,29]$, as well as managing homegardens, raising of goats, cattle and sheep, and extraction of forest products; migration to cities of Mexico and the U. S. is also important in their economy [9].

\section{Production, incomes, and cultural aspects in homegardens}

We studied a total of 30 homegardens, ten in each of the three first environmental zones referred to above, and considered and compared our information with that 


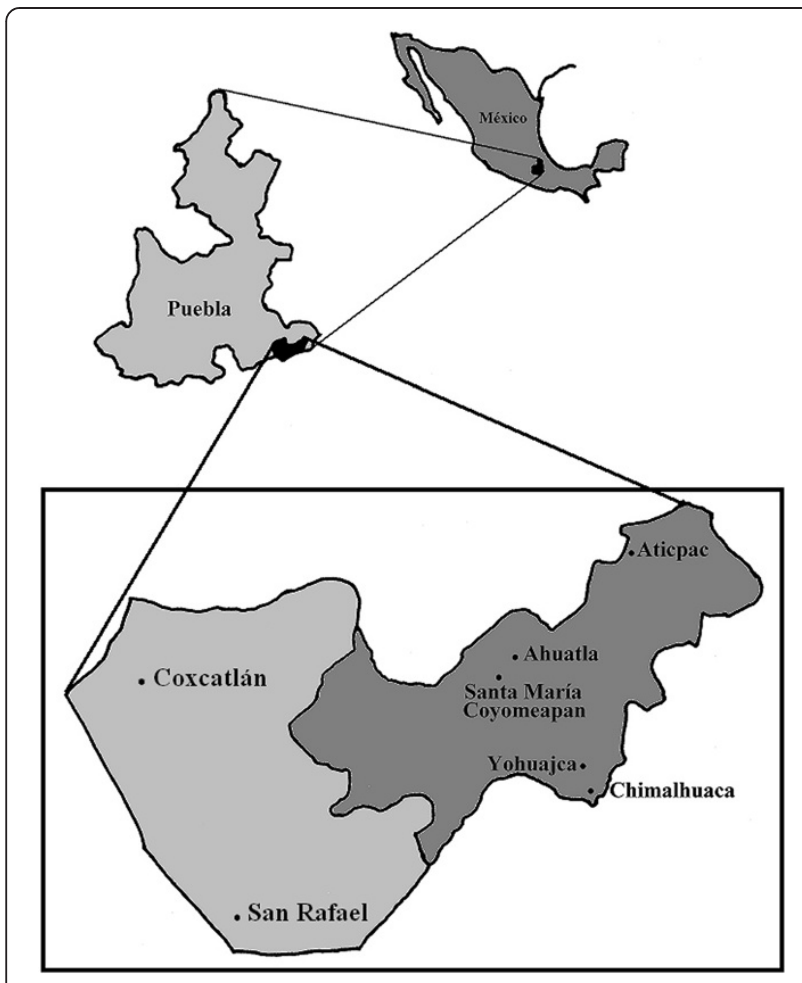

Figure 1 Study area. Communities studied in the municipalities of Coyomeapan and Coxcatlán in the state of Puebla, central México.

reported by Blanckaert et al. [20] for homegardens of the TSFZ. Homegardens studied were randomly sampled through a list of households in a village, assigning a number to them and then generating random numbers in a calculator. Semi-structured interviews [42] were conducted to the owners of each homegarden sampled, including questions on uses, names, management types, production and role of plant species of the system in the household's subsistence. Native language is Náhuatl, after asking permit to carry out the study in communitarian meetings we interviewed 28 persons in Spanish since they were bilingual (Náhuatl and Spanish) and two persons only Náhuatl speakers were interviewed with the help of a local translator. Voucher specimens and photographs of each species recorded were prepared and information documented following the collecting format of the ethnobotanical data bank of Mexico, Banco de Datos Etnobotánicos de Plantas de México (BADEPLAN), of the Botanical Garden at UNAM.

We calculated the total amount of products obtained per homegarden through surveys and interviews about production per individual plant of a species, transforming the different local units of measurements (e.g. "caja", "manojo", "pieza", "docena", "bolsa") in kg, and then by using data of vegetation sampling we estimated the total production in each homegarden. Proportions of products consumed directly by households and commercialized were estimated qualitatively by using as visual stimulus an image of a pie divided into five parts. We estimated incomes from the products of homegardens by investigating their prices through a survey carried out between August and October 2012, transforming their prices in Mexican pesos to U.S. dollars according to the exchange rate in that period. All the information referred to was stored in a database, and all quantitative analyses were conducted through the programme Past.

\section{Ecological parameters evaluated}

We measured the area of each homegarden, constructed maps indicating the disposition of plant areas and other components of the systems, recording the number of individuals of each plant species within the whole homegardens. With this information we calculated the species richness, diversity and dominance per homegarden. Richness was determined as the total number of species per homegarden and then averaged this figure per environmental zone. Abundance was calculated as the total number of individual plants of each species per homegarden. Frequency was estimated as the number of individuals of a plant species with respect the total number of individual plants composing a homegarden. With these parameters we calculated the ecological importance index of each species per homegarden. Diversity was estimated by the Shannon-Wiener index. Then we calculated the dominance as a measure of representativeness of each species through the Simpson index. Equity, the proportion of the observed diversity with respect the maximum diversity expected was calculated through the Pielou index: $\boldsymbol{J}=\boldsymbol{H}^{\prime} / \boldsymbol{H}^{\prime}$ $\max$, in which $\boldsymbol{J}$ is Equity; $\boldsymbol{H}^{\prime}=$ diversity; $\boldsymbol{H}_{\max }^{\prime}=$ maximum diversity. H'max was calculated as the $\ln (\boldsymbol{S}) \boldsymbol{S}$ being the number of species in a sample. Similarity among the sampled units was estimated through the Jaccard index.

We sampled seven sites of natural vegetation $\left(500 \mathrm{~m}^{2}\right.$ each site); three in the CFZ, two in the TRFZ, and two in the TDFZ in order to compare their composition in perennial plant species with that of the homegardens studied. For conducting a similar comparison in the homegardens of the village of San Rafael we considered the information of two additional sites sampled by Vivar [41] in the Thorn-Scrub Forest locally called 'jiotillal' (dominated by the 'jiotilla' Escontria chiotilla) in the natural area around this village. With this information we determined the proportion of local diversity maintained within homegardens.

\section{Results}

Floristic composition and ecological parameters of homegardens

Species richness and diversity

Area of homegardens in Coyomeapan and Ahuatla averaged $805 \mathrm{~m}^{2} \pm$ D.S 550.98; in Aticpac $350 \mathrm{~m}^{2} \pm$ D.S 


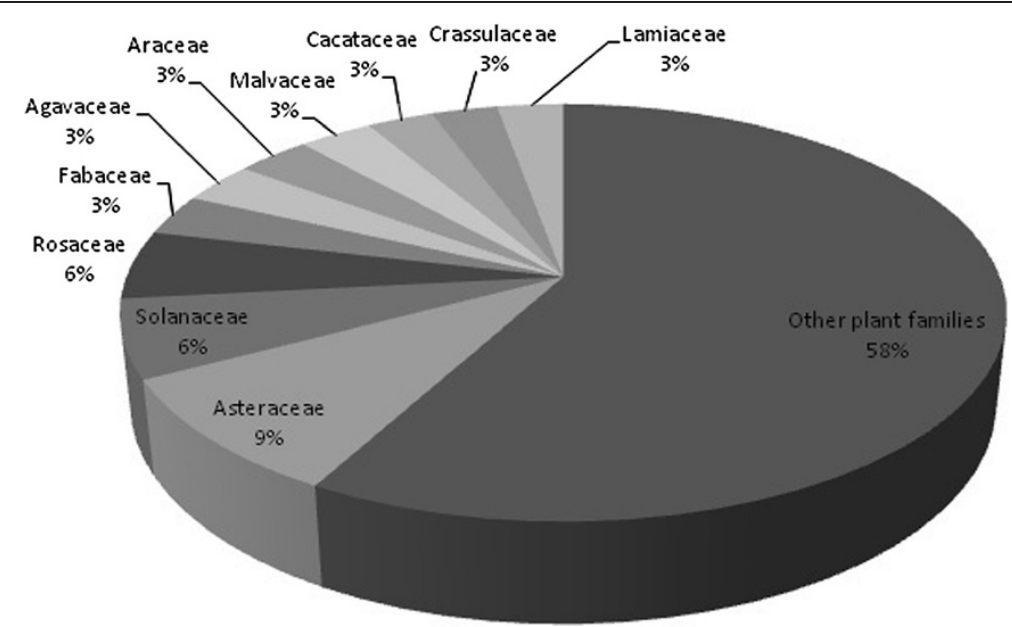

Figure 2 Plant families with the highest species richness recorded in the homegardens studied.

168.33, whereas in Chimalhuaca and Yohuajca $300 \mathrm{~m}^{2} \pm$ D.S 156.35. All parcels sampled are private property of the people interviewed. Most homegardens are in flatlands but in Coyomeapan and Ahuatla are on slight slope terrain. In the whole area sampled we recorded a total of 281 plant species belonging to 91 plant families, the richest one being Asteraceae (26 species), Solanaceae (17 species), Rosaceae (15 species) and Fabaceae (9 species) (Figure 2).

A total of 151 of the species recorded (34\%) are native of the Tehuacán Valley, 20\% are native in other areas of Mexico, and 130 (46\%) are species introduced from other parts of the World. Herbs were the most numerous species $(47 \%)$ in the homegardens studied, followed by trees $(21 \%)$ and shrubs $(20 \%)$. The remaining $12 \%$ of the species were other arborescent, vine, globose and cilindric cacti, and rosetophyllous plants. Figures 3, 4 and 5 shows species more frequently recorded in homegardens of the CFZ, TRFZ, and TDFZ. The highest species richness, diversity and equitability were recorded in homegardens of the CFZ, followed by those of the TRFZ, and then by those of the TDFZ (Table 1, Figure 6). This result contrasts with that found in natural vegetation; as it is shown in Table 2, the highest species richness and diversity were recorded in the Tropical Dry Forest (72 specie, $\boldsymbol{H}=3.562$ ), followed by the Tropical Rainforest (40 species, $\boldsymbol{H}=2.74$ ) and the Cloud Forest (24 species and $\boldsymbol{H}=2.016$ ). In the ThornScrub Forest, Vivar (2004) recorded 69 plant species and estimated $\boldsymbol{H}=1.28$ (Table 2).

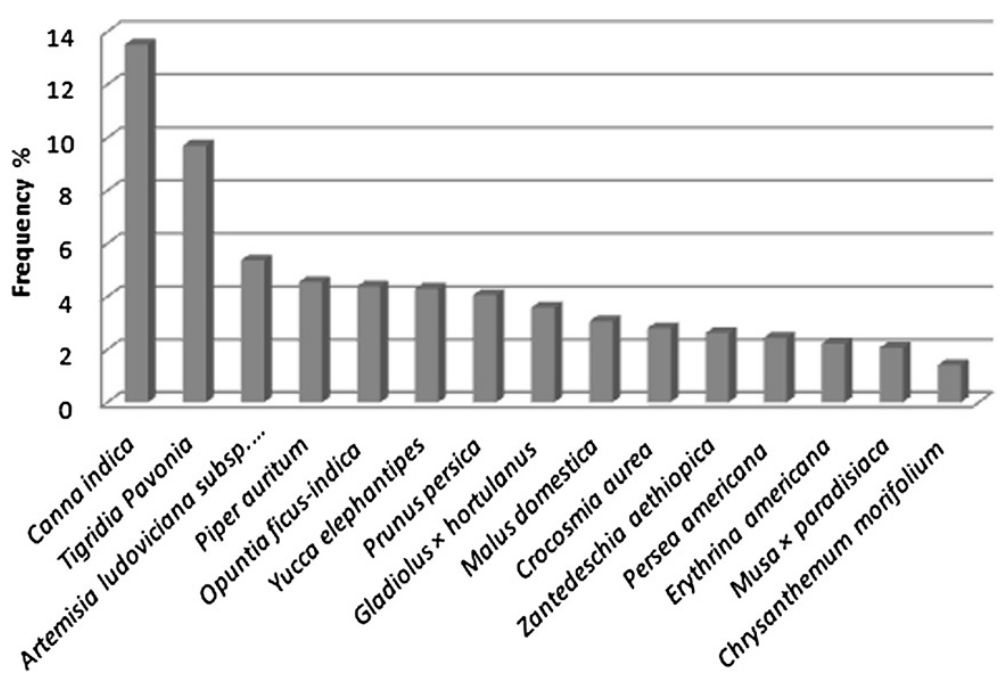

Figure 3 Frequencies of plant species recorded in the homegardens of Cloud Forest Zone (CFZ) at the communities of Coyomeapan and Ahuatla. 


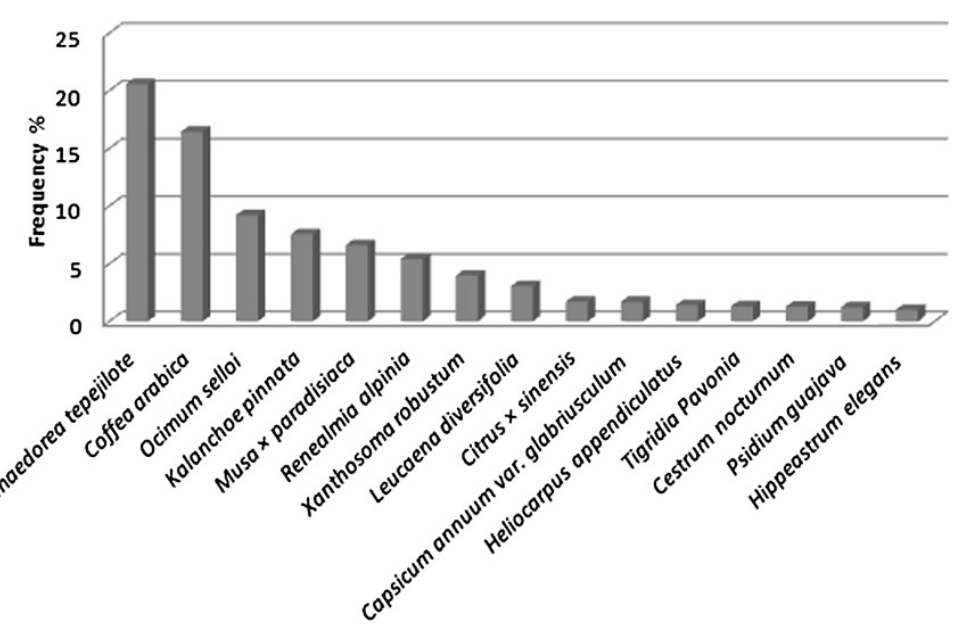

Figure 4 Frequencies of plant species recorded in the homegardens of Tropical Rainforest Zone (TRFZ) at the community of Aticpac.

\section{Similarity of plant composition}

Homegardens from the CFZ shared 108 species with those of the TRFZ (38.4\% of the total number of species recorded in both areas), and 96 (34.1\%) species with homegardens from the TDFZ. Homegardens from the TRFZ shared 86 (30.6\%) species with those from the TDFZ. A total of 73 species (25.9\% of all recorded in the whole sample) were shared among homegardens of the three zones directly studied.

\section{Benefits provided by homegardens}

According to perception of local people, homegardens provide the following main benefits: (1) complementing food, (2) closer availability of medicines, (3) obtaining monetary incomes, (4) complementing fuel wood and coffee, (5) obtaining shade, (6) soil retention, and (7) pleasure of being surrounded by ornamental beautiful plants. A total of 249 species were reported as having one use type, 30 species having two use types, and 2 species with three use types. The most numerous species were ornamental, followed by edible, medicinal, ritual, condiment, material for construction, living fences, fuelwood, shade, and tools (Figure 7).

A total of 89 native species were recorded in homegardens of the CFZ, most of them ornamental plants (39 species), followed by edible plants (32 species), medicinal plants (14 species) and other uses (14 species). In homegardens of the TRFZ we recorded 86 native species, most of them edible plants (32 spp.), followed by ornamental plants (28 spp.), medicinal plants (18 spp.), and other uses (16 spp.). In homegardens of the TDFZ we recorded 69 native species, most of them edible plants

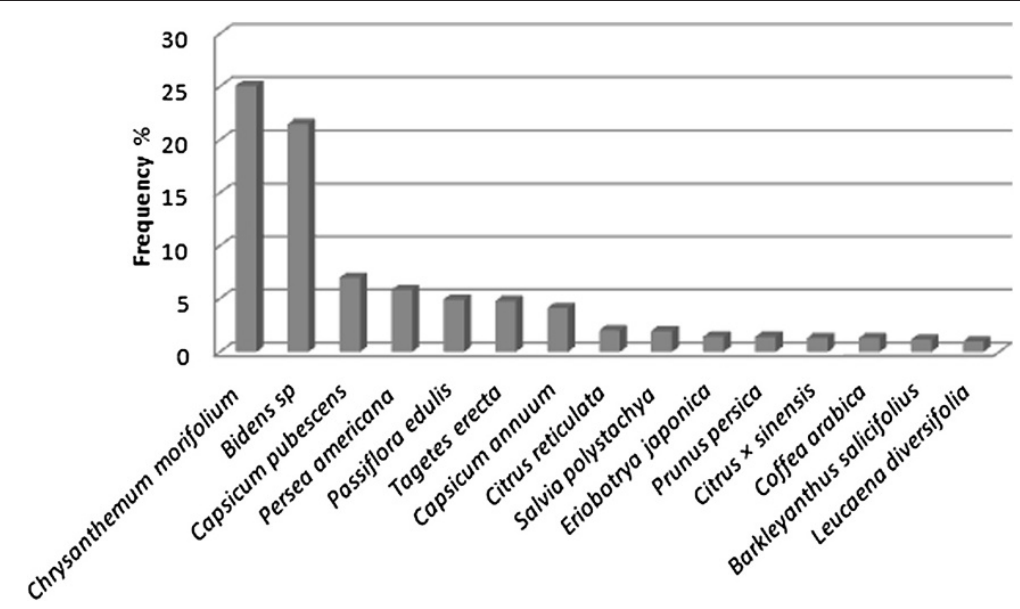

Figure 5 Frequencies of plant species recorded in the homegardens of Tropical Dry Forest Zone (TDFZ) at the communities of Chimalhuaca and Yohuajca. 
Table 1 Species richness, diversity $\left(\mathrm{H}^{\prime}\right.$ = Shannon-Wiener index), dominance and equitability in homegardens of the studied zones

\begin{tabular}{|c|c|c|c|c|c|c|c|}
\hline Environmental zone & Home garden & Area $\left(\mathrm{m}^{2}\right)$ & $\begin{array}{l}\text { Number of } \\
\text { plant species }\end{array}$ & Number of individual plants & Diversity $\left(\mathrm{H}^{\prime}\right)$ & Dominance & Equitability \\
\hline CFZ & 1 & 550 & 68 & 777 & 3.071 & 0.918 & 0.727 \\
\hline CFZ & 2 & 1400 & 92 & 2687 & 3.041 & 0.918 & 0.672 \\
\hline CFZ & 3 & 600 & 94 & 1116 & 3.092 & 0.884 & 0.68 \\
\hline CFZ & 4 & 500 & 73 & 1384 & 2.675 & 0.833 & 0.623 \\
\hline CFZ & 5 & 1000 & 89 & 1364 & 3.043 & 0.89 & 0.678 \\
\hline CFZ & 6 & 2000 & 57 & 1184 & 2.81 & 0.906 & 0.695 \\
\hline CFZ & 7 & 900 & 45 & 680 & 2.64 & 0.874 & 0.693 \\
\hline CFZ & 8 & 100 & 66 & 2058 & 2.8 & 0.862 & 0.668 \\
\hline CFZ & 9 & 400 & 46 & 801 & 3.225 & 0.944 & 0.842 \\
\hline CFZ & 10 & 600 & 35 & 591 & 2.703 & 0.898 & 0.76 \\
\hline$x$ & & 805 & 66.5 & 1264 & 2.91 & 0.89 & 0.70 \\
\hline$\sigma$ & & 550.98 & 20.88 & 662.79 & 0.21 & 0.03 & 0.06 \\
\hline TRFZ & 11 & 400 & 91 & 1290 & 3.153 & 0.91 & 0.698 \\
\hline TRFZ & 12 & 150 & 34 & 245 & 2.708 & 0.892 & 0.768 \\
\hline TRFZ & 13 & 600 & 32 & 644 & 2.035 & 0.79 & 0.587 \\
\hline TRFZ & 14 & 150 & 11 & 53 & 1.878 & 0.774 & 0.783 \\
\hline TRFZ & 15 & 200 & 31 & 236 & 2.627 & 0.884 & 0.765 \\
\hline TRFZ & 16 & 300 & 69 & 969 & 2.686 & 0.844 & 0.634 \\
\hline TRFZ & 17 & 400 & 58 & 1587 & 2.126 & 0.783 & 0.523 \\
\hline TRFZ & 18 & 250 & 47 & 736 & 2.308 & 0.817 & 0.599 \\
\hline TRFZ & 19 & 600 & 39 & 1062 & 2.129 & 0.802 & 0.581 \\
\hline TRFZ & 20 & 450 & 49 & 1420 & 2.195 & 0.795 & 0.564 \\
\hline$x$ & & 350 & 46.10 & 824.20 & 2.38 & 0.83 & 0.65 \\
\hline$\sigma$ & & 168.33 & 22.48 & 532.06 & 0.39 & 0.05 & 0.10 \\
\hline TDFZ & 21 & 500 & 43 & 574 & 2.801 & 0.898 & 0.744 \\
\hline TDFZ & 22 & 600 & 37 & 444 & 2.578 & 0.857 & 0.713 \\
\hline TDFZ & 23 & 250 & 14 & 47 & 2.427 & 0.895 & 0.919 \\
\hline TDFZ & 24 & 200 & 34 & 2452 & 2.217 & 0.846 & 0.628 \\
\hline TDFZ & 25 & 100 & 37 & 281 & 2.508 & 0.853 & 0.694 \\
\hline TDFZ & 26 & 250 & 29 & 254 & 2.807 & 0.914 & 0.833 \\
\hline TDFZ & 27 & 150 & 45 & 175 & 3.208 & 0.939 & 0.842 \\
\hline TDFZ & 28 & 250 & 63 & 3933 & 1.966 & 0.768 & 0.474 \\
\hline TDFZ & 29 & 400 & 19 & 1508 & 1.029 & 0.421 & 0.349 \\
\hline TDFZ & 30 & 300 & 46 & 3537 & 1.007 & 0.35 & 0.262 \\
\hline$x$ & & 300 & 36.70 & 1320.50 & 2.25 & 0.77 & 0.65 \\
\hline$\sigma$ & & 156.35 & 14.07 & 1473.13 & 0.73 & 0.21 & 0.22 \\
\hline
\end{tabular}

CFZ = Cloud Forest Zone; TRFZ = Tropical Rainforest Zone; TDFZ = Tropical Dry Forest Zone.

(28 spp.), followed by ornamental plants (18 spp.), medicinal plants (13 spp.), and other uses (16 spp., Table 3).

People surveyed said that most of the products from homegardens (67.1\%) are destined to commercialization and the remaining part (32.9\%) for direct consumption by household. A total of 43 species (15\% of the total recorded) generate monetary incomes, but most species (238, $85 \%$ of the total recorded) are not interchanged. Main species from homegardens commercialized are indicated in Tables 4 and 5. 


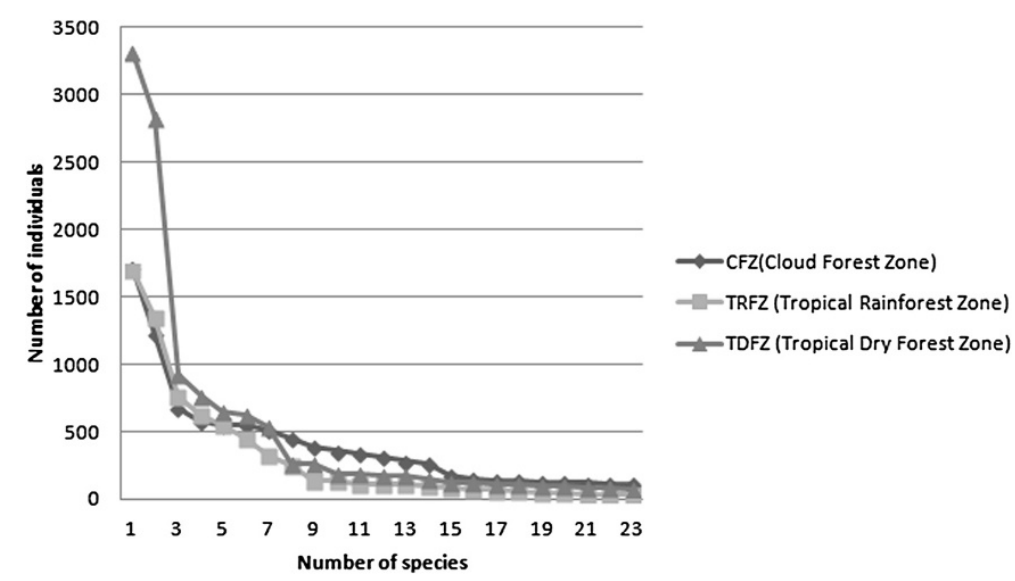

Figure 6 Curve of species accumulated in vegetation sampling of homegardens, from higher to lower number of species at the communities of Coyomeapan, Ahuatla, Aticpac, Chimalhuaca y Yojhuaca. Coyomeapan, Puebla. CFZ = Cloud Forest Zone, TRFZ = Tropical Rainforest Zone, TDFZ = Tropical Dry Forest Zone.

Other species such as apple (Malus domestica), prunes (Prunus domestica), peaches, canario chili (Capsicum pubescens), granadilla or passion fruit (Passiflora edulis) and custard apple (Annona cherimola) are also commercialized in markets, but these are mainly traded to foreign hoarders in the place of Coyomeapan. Hoarders pay low and unfair prices to local people for their products to commercialize them at higher prices in markets of the cities of Tehuacán, Ajalpan, and Zoquitlán in the state of Puebla, Zongolica, in the state of Veracruz and Teotitlán, in the state of Oaxaca. Barter is also a common practice exchanging a variety of products for maize and coffee.

\section{Plant management \\ Management types}

A total of 176 species recorded in the homegardens studied are cultivated, 71 species are native tolerated or let standing and 34 are enhanced or promoted. A total of 151 of the managed plant species are native (71 cultivated, 57 tolerated, and 23 enhanced, Tables 3 and 4). It can be noticed that the sum of the species mentioned is higher than the total recorded, because several species have more than one management type.

\section{Spatial arrangement}

A general pattern of spatial arrangement of plant species in homegardens were identified. Herbaceous, shrubby and vine plants providing benefits as ornamental, medicinal, and condiment are placed close to the houses, because according to local people these species generally require irrigation, they make beautiful their houses and provide medicines promptly when needed. Some tall trees are also placed close to the house, mainly Alnus acuminata (30\% of all homegardens sampled), Quercus spp. (23\%), Cupressus spp. (20\%), Fraxinus uhdei (20), Salix taxifolia (13\%), and Platanus mexicana (7\%); according to people, these are trees destined to provide shade to the houses and to protect them against strong wind. Fruit producing trees and other large tree species are placed distanced from houses because, according to people, these species have extended roots that may affect the houses' floor, and because their eventual falling down may destroy the house. In Coyomeapan and Ahuatla (CFZ) homegardens are delimited by living fences more commonly formed with Erythrina americana (50\% of all homegardens of the CFZ), Yucca elephantipes (40\%), Brugmansia candida (40\%), Quercus laurina (23\%), Fraxinus uhdei (20\%), Arundo donax (20\%), Cupressus spp. (20\%), and Jasminum fruticans (17\%). In Aticpac (TRFZ) people construct fences with stones and Hibiscus rosa-sinensis (50\% of all homegardens of this village), whereas in Chimalhuaca and Yohuajca (TDFZ) there are no living fences.

\section{Maintenance of homegardens}

Women are the main managers of homegardens, practicing sowing, planting, maintenance and harvest of most products; also they are the main responsible of trading their products. Men participate in activities such as tree pruning, weeding, fertilization and actions against pests and harvesting of some products, mainly those of tall trees. Widows use to pay a salary (nearly $\$ 6.50$ U.S. dollars per day) to men for doing these activities.

People from Coyomeapan, Ahuatla, Chimalhuaca and Yohuajca (CFZ and TDFZ) use to regularly add as fertilizer ground collected in the forest ('tierra de monte'), ash from home fire, dung of hens, sheep and goats. In 
Table 2 Species richness and diversity (Shannon-Wiener index) in natural vegetation of the studied zones

\begin{tabular}{|c|c|c|c|c|c|}
\hline Cloud forest zone & $\mathrm{H}^{\prime}=$ & 2.016 & Species richness: & 24 spp. & \\
\hline Species & Abundance & Relative frequency & Relative density & Relative dominance & Ecological value \\
\hline Quercus laurina & 380 & 15.625 & 34.959 & 26.899 & 77.483 \\
\hline Quercus candicans & 261 & 11.458 & 24.011 & 23.774 & 59.244 \\
\hline Ternstroemia sp. & 73 & 10.417 & 6.716 & 7.658 & 24.790 \\
\hline Vaccinium leucanthum & 96 & 5.208 & 8.832 & 8.781 & 22.821 \\
\hline Styrax argenteus & 96 & 5.208 & 8.832 & 7.812 & 21.852 \\
\hline Baccharis conferta & 60 & 7.292 & 5.520 & 6.296 & 19.107 \\
\hline Pinus sp. & 40 & 6.250 & 3.680 & 4.404 & 14.334 \\
\hline Clethra sp. & 29 & 6.250 & 2.668 & 3.510 & 12.428 \\
\hline Morella cerifera & 14 & 5.208 & 1.288 & 1.551 & 8.047 \\
\hline Eupatorium sp. & 17 & 4.167 & 1.564 & 1.727 & 7.458 \\
\hline Arbutus xalapensis & 11 & 4.167 & 1.012 & 1.320 & 6.499 \\
\hline Quercus crassifolia & 6 & 4.167 & 0.552 & 0.713 & 5.431 \\
\hline Rubus sp. & 2 & 2.083 & 0.184 & 0.231 & 2.498 \\
\hline Litsea glaucescens & 2 & 2.083 & 0.184 & 0.225 & 2.492 \\
\hline Tropical rain forest zone & & $H^{\prime}=2.744$ & Species richness: & 40 spp. & \\
\hline Species & Abundance & Relative frequency & Relative density & Relative dominance & Ecological value \\
\hline Chamaedorea tepejilote & 80 & 6.757 & 30.769 & 15.621 & 53.147 \\
\hline Aphelandra scabra & 40 & 5.405 & 15.385 & 6.002 & 26.792 \\
\hline Piper sp. & 19 & 6.757 & 7.308 & 6.346 & 20.411 \\
\hline Guarea glabra & 11 & 5.405 & 4.231 & 8.450 & 18.086 \\
\hline Parmentiera aculeata & 4 & 2.703 & 1.538 & 10.575 & 14.816 \\
\hline Aphananthe monoica & 5 & 4.054 & 1.923 & 7.729 & 13.706 \\
\hline Miconia aff. Argentea & 12 & 4.054 & 4.615 & 1.657 & 10.327 \\
\hline Comarostaphylis sp. & 9 & 4.054 & 3.462 & 0.507 & 8.022 \\
\hline Albizia sp. & 5 & 4.054 & 1.923 & 1.968 & 7.945 \\
\hline Oreopanax xalapensis & 2 & 1.351 & 0.769 & 5.105 & 7.226 \\
\hline Ruprechtia sp. & 1 & 1.351 & 0.385 & 5.016 & 6.752 \\
\hline Maclura tinctoria & 2 & 1.351 & 0.769 & 4.074 & 6.194 \\
\hline Heliocarpus appendiculatus & 3 & 4.054 & 1.154 & 0.333 & 5.541 \\
\hline Coccoloba grandifolia & 2 & 2.703 & 0.769 & 1.336 & 4.808 \\
\hline Parathesis sp. & 2 & 1.351 & 0.769 & 1.663 & 3.784 \\
\hline Inga vera & 1 & 1.351 & 0.385 & 1.254 & 2.990 \\
\hline Sapindus saponaria & 1 & 1.351 & 0.385 & 0.831 & 2.567 \\
\hline Eugenia capulí & 1 & 1.351 & 0.385 & 0.495 & 2.231 \\
\hline Dendropanax arboreus & 1 & 1.351 & 0.385 & 0.066 & 1.802 \\
\hline Trema micrantha & 1 & 1.351 & 0.385 & 0.041 & 1.777 \\
\hline Tropical dry forest zone & $H^{\prime}=$ & 3.562 & Species richness: & 72 spp. & \\
\hline Species & Abundance & Relative frequency & Relative density & Relative dominance & Ecological value \\
\hline Lippia graveolens & 256 & 1.592 & 14.144 & 22.074 & 37.809 \\
\hline Jatropha dioica & 94 & 2.387 & 5.193 & 9.261 & 16.842 \\
\hline Dasylirion serratifolium & 26 & 2.122 & 1.436 & 11.479 & 15.037 \\
\hline Dalea bicolor & 104 & 2.122 & 5.746 & 5.593 & 13.461 \\
\hline Neopringlea sp & 74 & 2.122 & 4.088 & 6.014 & 12.224 \\
\hline
\end{tabular}


Table 2 Species richness and diversity (Shannon-Wiener index) in natural vegetation of the studied zones (Continued)

\begin{tabular}{|c|c|c|c|c|c|}
\hline Gymnosperma glutinosa & 118 & 2.387 & 6.519 & 0.662 & 9.569 \\
\hline Lippia sp. & 58 & 2.653 & 3.204 & 2.340 & 8.197 \\
\hline Dodonaea viscosa & 70 & 2.653 & 3.867 & 0.988 & 7.508 \\
\hline Calia secundiflora & 16 & 1.061 & 0.884 & 5.140 & 7.085 \\
\hline Turnera diffusa & 76 & 1.326 & 4.199 & 1.186 & 6.711 \\
\hline Calea sp. & 30 & 1.592 & 1.657 & 2.949 & 6.198 \\
\hline Zaluzania sp. & 32 & 2.653 & 1.768 & 1.733 & 6.153 \\
\hline Lysiloma acapulcensis & 46 & 2.653 & 2.541 & 0.898 & 6.092 \\
\hline Eysenhardtia polystachya & 2 & 0.531 & 0.110 & 5.065 & 5.706 \\
\hline Senna sp. & 46 & 2.122 & 2.541 & 0.953 & 5.616 \\
\hline Galphimia glauca & 24 & 2.653 & 1.326 & 1.249 & 5.227 \\
\hline Tecoma stans & 40 & 1.857 & 2.210 & 0.550 & 4.616 \\
\hline Pilosocereus chrysacanthus & 10 & 2.122 & 0.552 & 1.560 & 4.235 \\
\hline Opuntia pilifera & 12 & 2.122 & 0.663 & 1.347 & 4.132 \\
\hline Ipomoea arborescens & 24 & 1.592 & 1.326 & 0.833 & 3.751 \\
\hline Brickellia sp. & 10 & 2.122 & 0.552 & 1.004 & 3.679 \\
\hline Mimosa sp. & 10 & 1.061 & 0.552 & 2.023 & 3.637 \\
\hline Lantana cámara & 20 & 1.592 & 1.105 & 0.877 & 3.573 \\
\hline Beaucarnea gracilis & 16 & 1.592 & 0.884 & 0.987 & 3.462 \\
\hline Wimmeria sp. & 14 & 1.326 & 0.773 & 1.356 & 3.456 \\
\hline Mammillaria sp. & 24 & 1.592 & 1.326 & 0.321 & 3.238 \\
\hline Pittocaulon praecox & 10 & 2.122 & 0.552 & 0.547 & 3.221 \\
\hline Indigofera sp. & 10 & 1.592 & 0.552 & 0.891 & 3.035 \\
\hline Plumeria rubra & 8 & 1.592 & 0.442 & 0.659 & 2.692 \\
\hline Senna fruticosa & 10 & 1.061 & 0.552 & 0.897 & 2.510 \\
\hline Agave potatorum & 12 & 1.326 & 0.663 & 0.269 & 2.258 \\
\hline Wimmeria microphylla & 20 & 0.531 & 1.105 & 0.451 & 2.086 \\
\hline Pseudosmodingium sp. & 4 & 1.061 & 0.221 & 0.797 & 2.079 \\
\hline Indigofera cuernavacana & 4 & 1.061 & 0.221 & 0.789 & 2.071 \\
\hline Thorn-scrub forest zone & $H^{\prime}=$ & 1.28 & Species richness: & 69 spp. & \\
\hline Species & Abundance & Relative frequency & Relative density & Relative dominance & Ecological value \\
\hline Mammillaria carnea & 127 & 14.85 & 8.44 & 0.42 & 23.71 \\
\hline Gomphrena decumbens & 71 & 8.26 & 4.70 & 0.85 & 13.82 \\
\hline Panicum sp. & 66 & 7.68 & 4.37 & 0.35 & 12.40 \\
\hline Opuntia pilifera & 38 & 4.42 & 2.51 & 5.90 & 12.82 \\
\hline Loeselia glandulosa & 34 & 3.99 & 2.27 & 0.05 & 6.30 \\
\hline Dalea carthagenensis & 32 & 1.99 & 1.13 & 0.59 & 3.72 \\
\hline Chamaesyce cumbrae & 32 & 3.69 & 2.10 & 0.16 & 5.95 \\
\hline Euphorbia heterophylla & 28 & 3.28 & 1.87 & 0.08 & 5.22 \\
\hline Zinnia peruviana & 24 & 2.81 & 1.60 & 0.29 & 4.70 \\
\hline Pectis haenkeana & 22 & 1.93 & 1.10 & 0.46 & 3.50 \\
\hline Mimosa luisana & 21 & 2.46 & 1.40 & 20.20 & 24.06 \\
\hline Stenocereus stellatus & 21 & 2.42 & 1.38 & 1.25 & 5.05 \\
\hline Coryphantha pycnacantha & 19 & 2.23 & 1.27 & 0.04 & 3.54 \\
\hline Viguiera dentata & 17 & 0.82 & 0.47 & 2.27 & 3.56 \\
\hline
\end{tabular}


Table 2 Species richness and diversity (Shannon-Wiener index) in natural vegetation of the studied zones (Continued)

\begin{tabular}{|c|c|c|c|c|c|}
\hline Dalea sp. & 17 & 3.75 & 2.13 & 1.58 & 7.47 \\
\hline Escontria chiotilla & 17 & 1.99 & 1.13 & 20.81 & 23.94 \\
\hline Phaseolus sp. & 17 & 2.58 & 1.47 & 0.11 & 4.16 \\
\hline Opuntia puberula & 16 & 1.84 & 1.04 & 0.23 & 3.11 \\
\hline Carminatia alvarezii & 14 & 1.64 & 0.93 & 0.06 & 2.64 \\
\hline Lippia graveolens & 14 & 1.64 & 0.93 & 2.17 & 4.74 \\
\hline Physalis philadelphica & 14 & 1.58 & 0.90 & 0.56 & 3.04 \\
\hline Boerhavia erecta & 13 & 1.52 & 0.87 & 0.34 & 2.73 \\
\hline Mimosa polyantha & 11 & 1.29 & 0.73 & 8.38 & 10.41 \\
\hline Sanvitalia fruticosa & 10 & 1.17 & 0.67 & 0.06 & 1.90 \\
\hline Croton sp. & 9 & 1.06 & 0.60 & 2.12 & 3.78 \\
\hline Cordia curassavica & 9 & 1.02 & 0.58 & 2.52 & 4.11 \\
\hline Celtis pallida & 8 & 0.94 & 0.53 & 0.60 & 2.07 \\
\hline Commelina erecta & 8 & 0.94 & 0.53 & 0.04 & 1.52 \\
\hline
\end{tabular}

CFZ = Cloud Forest Zone; TRFZ = Tropical Rainforest Zone; TDFZ = Tropical Dry Forest Zone; TSFZ = Thorn-Scrub Forest Zone (based on Vivar [41]). Only the most important species are reported.

Aticpac (TRFZ) people leave the fallen leaves of plants to recycling into the soil and occasionally add forest ground to some particular plants, mainly fruit trees.

The general opinion of local people is that pests are not a real problem; however, people from Coyomeapan and Ahuatla (CFZ), add lime to fruit trees trunks in order to prevent ants and aphid attack; this method also allows controlling lichen growing since people consider that lichens "robe life to trees" affecting fruit production. Branches of big trees such as oaks, alder and ash trees are pruned when the hemi-parasite plant called "tempala" (Phoradendron sp.) infests them. In Aticpac (TRFZ) people use to remove by hand worms infesting plants in homegardens; ants and "cenicilla" (Oidium sp.) are prevented by putting lime on tree trunks. In Chimalhuaca and Yohuajca (TDFZ) people make use of agrochemical products to prevent pest attack since they cultivate ornamental plants close to the homegardens and they consider that pests of those crops will extend rapidly to homegardens.

Pruning is also practiced to control tree growing in order to make harvesting easy. Herbaceous and shrubby plants close to the houses are irrigated every three days during the dry season. Fruit trees are only occasionally irrigated.

\section{Discussion}

Our study confirmed that the homegardens studied harbour a high biological diversity represented by a total

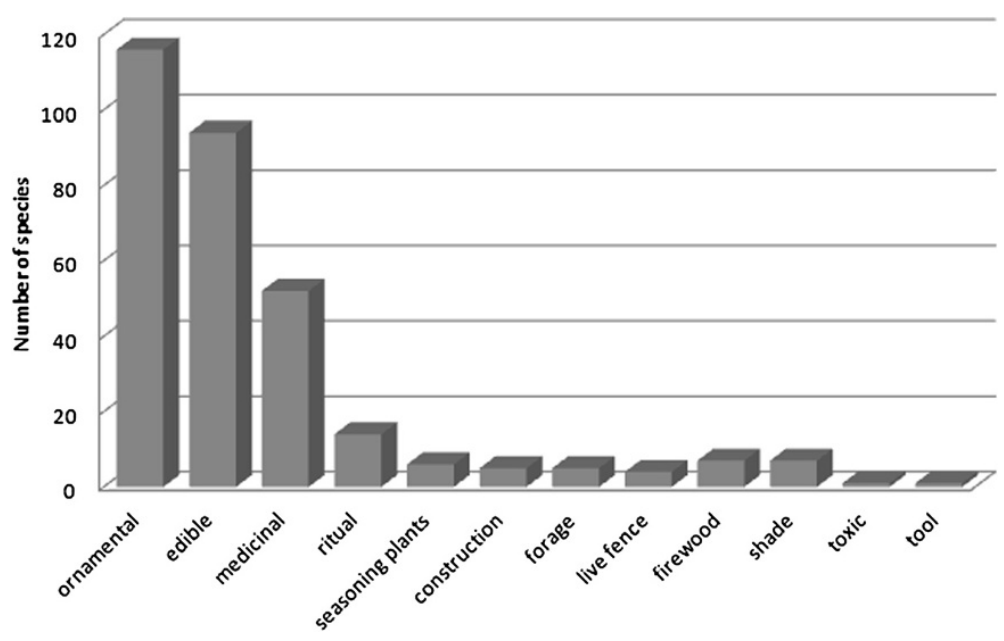

Figure 7 Uses of the plant species recorded in the homegardens of all the communities studied in the municipality of Coyomeapan. 
Table 3 Total number and percentage of cultivated, enhanced and tolerated native plant species with different use types recorded in all the homegardens studied

\begin{tabular}{|c|c|c|}
\hline Management type & Use & $\begin{array}{l}\text { Number and percentage } \\
\text { of species }\end{array}$ \\
\hline \multirow[t]{5}{*}{ Cultivated } & TOTAL & 71 spp. (100.0\%) \\
\hline & Ornamental & 35 spp. (49.2\%) \\
\hline & Edible & 30 spp. (42.2\%) \\
\hline & Medicinal & 7 spp. (9.8\%) \\
\hline & Others & 4 spp. (5.6\%) \\
\hline \multirow[t]{5}{*}{ Enhanced } & TOTAL & 23 spp. (100.0\%) \\
\hline & Ornamental & 7 spp. (28.0\%) \\
\hline & Edible & 11 spp. (44.0\%) \\
\hline & Medicinal & 5 spp. (20.0\%) \\
\hline & Others & $3(12.0 \%)$ \\
\hline \multirow[t]{5}{*}{ Tolerated } & TOTAL & 57 spp. (100.0\%) \\
\hline & Ornamental & 10 spp. (17.5\%) \\
\hline & Edible & 8 spp. (14.0\%) \\
\hline & Medicinal & 21 spp. (36.8\%) \\
\hline & Others & 24 spp. (42.1\%) \\
\hline
\end{tabular}

of 281 plant species. Although lower than other traditional agroforestry systems of the region (see for instance $[7,29]), 34 \%$ of the plant species maintained in homegardens are native to the region and $16 \%$ are native to local vegetation of the territories analysed. Such

Table 4 Number of native plant species used with different purposes in the different environmental zones studied

\begin{tabular}{llll}
\hline Zone & Use & $\begin{array}{l}\text { Number of } \\
\text { native plant } \\
\text { species }\end{array}$ & $\begin{array}{l}\text { \% of native } \\
\text { plant species } \\
\text { recorded }\end{array}$ \\
\hline Cloud forest & Ornamental & 39 & 43.8 \\
& Edible & 32 & 35.9 \\
& Medicinal & 14 & 15.7 \\
& Others & 14 & 15.7 \\
& TOTAL & 89 & 100 \\
Tropical rainforest & Ornamental & 28 & 32.6 \\
& Edible & 32 & 37.2 \\
& Medicinal & 18 & 20.9 \\
& Others & 16 & 18.6 \\
& TOTAL & 86 & 100.0 \\
Tropical dry forest & Ornamental & 18 & 26.1 \\
& Edible & 28 & 40.6 \\
& Medicinal & 13 & 18.8 \\
& Othrs & 16 & 23.2 \\
& TOTAL & 69 & 100.0 \\
\hline
\end{tabular}

diversity reflects in first term the cultural interest of local people for maintaining multiple options for complementing their subsistence patterns, including food and other needs security. The local human cultures studied, as the Mesoamerican peoples in general, have solved their subsistence needs by the multiple forms of using natural resources and ecosystems [43]. But the high diversity recorded in this study also reflects the high biodiversity of natural ecosystems of the Tehuacán Valley, one of the highest biodiverse regions of Mexico [34]. Several authors (see for instance [44]), have discussed that homegardens commonly resemble the structure of natural ecosystems. The diversity in composition, structure and functions are human constructions and are apparently inspired in the surrounding ecosystems.

We should highlight that along with the local plant species diversity maintained in homegardens there is also an associated diversity [5] involving other groups of organisms (e.g. birds, insects, mammals) which we have not evaluated yet but that find in homegardens favourable habitats for reproducing their lives. General diversity (not only that of native plant species) is in theory highly relevant for the system resilience, and local and regional policies for biodiversity conservation have in homegardens targets for enhancing their richness and composition with particularly endangered species or those that could favour local associated diversity.

Species richness, diversity and equitability were higher in homegardens of the CFZ, followed by those of the TRFZ and then those of the TDFZ. Contrarily to our expectations, the highest diversity was recorded in homegardens where the neighbouring forests had the least diversity and vice versa. This pattern suggests that local people manage in homegardens mainly plant species that are not available in the wilderness close to their towns; at least for some species management appears to aim at compensating scarcity of naturally available plant resources. Based on sampling of natural vegetation we found that homegardens share with the local forests a total of 25 perennial plant species (Table 6), but nearly 100 species recorded are native to the region. In other words, although the capacity of homegardens to conserving local diversity is relatively low, their capacity for conserving regional biodiversity is high.

Composition of homegardens seems to be related with the local environmental conditions of the villages studied; those from CFZ, TRFZ and TDF zones are different in composition among zones but similar within each zone. Composition of the homegardens studied in Coxcatlán by Blanckaert et al. [20] is in turn markedly different to that recorded in our study. For instance, Blanckaert et al. [20] found that cacti are among the main components of this system. Such composition is influenced by the high cultural value of cacti $[17,23]$ but 
Table 5 Prices in U.S. dollars (rate change in August-October 2012) per commercialization unit and kg of useful plant products of species recorded in the homegardens studied which are traded in the markets of Coyomeapan

\begin{tabular}{|c|c|c|c|c|c|c|}
\hline Plant family & Species & Common name & Commercialization unit & kg/unit & Average price per unit & $\$ / \mathbf{k g}$ \\
\hline ANNONACEAE & Annona cherimola & Chirimoya & Caja & 10 & 3.08 & 0.31 \\
\hline ARECACEAE & Chamaedorea tepejilote & Tepejilote & Manojo & 0.5 & 0.38 & 0.76 \\
\hline ASTERACEAE & Chrysanthemum morifolium & Flor campechana & Docena & 0.3 & 0.76 & 2.56 \\
\hline CACTACEAE & Opuntia ficus-indica & Nopal & Penca & 0.6 & 0.38 & 0.64 \\
\hline CARYOPHYLLACEAE & Dianthus caryophyllus & Clavel & Docena & 0.3 & 1.15 & 3.8 \\
\hline CUCURBITACEAE & Sechium edule & Chayote & Pieza & 0.2 & 0.04 & 0.19 \\
\hline LAURACEAE & Persea americana & Aguacate & Caja & 10 & 3.46 & 0.35 \\
\hline MUSACEAE & Musa $\times$ paradisiaca & Plátano & $\mathrm{Kg}$ & 1 & 0.39 & 0.39 \\
\hline MYRTACEAE & Psidium guajava & Guayaba & Bolsa & 0.4 & 0.39 & 0.96 \\
\hline PASSIFLORACEAE & Passiflora edulis & Granadilla & Caja & 10 & 6.15 & 0.62 \\
\hline ROSACEAE & Malus domestica & Manzana & Caja & 10 & 3.65 & 0.37 \\
\hline ROSACEAE & Prunus persica & Durazno & Caja & 10 & 4.62 & 0.46 \\
\hline ROSACEAE & Eriobotrya japonica & Níspero & Caja & 10 & 3.85 & 0.39 \\
\hline ROSACEAE & Prunus serotina & Capulín & Bolsa & 0.5 & 0.39 & 0.77 \\
\hline ROSACEAE & Prunus domestica & Ciruela & Caja & 10 & 2.69 & 0.27 \\
\hline RUBIACEAE & Coffea arabica & Café tostado y molido & $\mathrm{Kg}$ & 1 & 6.92 & 6.92 \\
\hline RUBIACEAE & Coffea arabica & Café verde & $\mathrm{Kg}$ & 1 & 3.85 & 3.85 \\
\hline RUTACEAE & Citrus reticulata & Madarina & Bolsa & 1 & 0.39 & 0.39 \\
\hline RUTACEAE & Citrus $\times$ sinensis & Licor de naranja & $\mathrm{Lt}$. & 1 & 3.08 & 3.08 \\
\hline RUTACEAE & Citrus $\times$ sinensis & Naranja & $\mathrm{Kg}$ & 1.25 & 0.39 & 0.31 \\
\hline RUTACEAE & Citrus $x$ aurantifolia & Lima & Bolsa & 1 & 0.39 & 0.39 \\
\hline SOLANACEAE & Capsicum pubescens & Chile canario & Caja & 10 & 3.46 & 0.35 \\
\hline ZINGIBERACEAE & Renealmia alpinia & Belígmoli & Docena & 0.1 & 0.39 & 3.85 \\
\hline
\end{tabular}

Table 6 Plant species shared among homegardens and natural vegetation in the studied zones at Coyomepan, Puebla

\begin{tabular}{|c|c|c|c|c|}
\hline & CFZ & TRFZ & TDFZ & TSFZ \\
\hline & Chamaedora elegans & Cercocarpus macrophyllus & Acacia farnesiana & Acacia cochliacantha \\
\hline & Platanus mexicana & Chamaedora elegans & Salix taxifolia & Acalypha sp. \\
\hline & Plumeria rubra & Hamelia patens & & Celtis pallida \\
\hline & Rubus eriocarpus & Rubus eriocarpus & & Cercidium praecox \\
\hline & Salix taxifolia & Talauma mexicana & & Commelina erecta \\
\hline & & Siparuna andina & & Escontria chiotilla \\
\hline & & & & Ferocactus latispinus \\
\hline & & & & Lippia graveolens \\
\hline & & & & Physalis philadelphica \\
\hline & & & & Sedum sp. \\
\hline & & & & Stenocereus pruinosus \\
\hline & & & & Ziziphus amole \\
\hline Total: 25 & 5 & 6 & 2 & 12 \\
\hline *Percentage & $18.50 \%$ & $22.22 \%$ & $7.40 \%$ & ${ }^{+} 5.05 \%$ \\
\hline
\end{tabular}

* Percentage calculated based on the total number of species of trees and shrubs recorded in vegetation sampling of homegardens and natural vegetation in localities of Coyomeapan. ${ }^{+}$Percentage calculated based on the total number of species of trees, shrubs and herbs recorded in homegarden's vegetation sampling by Blanckaert et al. 2004 and wild jiotillal 's vegetation sampling by Vivar (2004) in San Rafael Coxcatlán. CFZ = Cloud Forest Zone, TRFZ = Tropical Rainforest Zone, TDFZ = Tropical Dry Forest Zone; TSFZ = Thorn-Scrub Forest Zone. 
also because of their adaptations to the local semiarid environment in Coxcatlán. Homegardens of the CFZ are significantly larger than those of the other zones studied, and that this aspect may influence composition of the system; however, according to [26] all the homegardens studied are within the 'small size' category.

Social factors also influence homegardens' composition. Although all the villages studied are neighbouring territories inhabited by Náhuatl people with similar culture, the economic purposes of homegardens vary among villages. Production of food (and monetary incomes derived from these products), medicines and ornamental are the most important purposes, and these factors guide criteria for making decisions about the composition of homegardens, but they are different among the villages studied as well as to those of Coxcatlán. For instance, in homegardens of the CFZ medicinal plants are scarcer than in the other zones. This could be associated to the decreasing importance of traditional medicine in communities of that zone which have public health centres and private clinics as well as transportation to urban centres. For the contrary, in those communities edible and ornamental plant species for commercialization are more important. In the communities of the other zones studied medical services are more deficient and traditional medicine more important, as well as composition of medicinal plants in homegardens. In communities of the TDFZ people cultivate ornamental plants for commercialization and this group of plants is therefore more important than others. Similarly, Blanckaert et al. [20] found that in Coxcatlán ornamental plant species of the families Araceae and Liliaceae are particularly important. In fact, ornamental purpose is relatively more important in Coxcatlán than in all villages of Coyomeapan (Table 7). These patterns show that homegardens are systems influenced by ecological conditions and restrictions, but also by cultural and

Table 7 Main plant families and species richness recorded in Coyomeapan (this study) and San Rafael, Coxcatlán (according to Blanckaert et al. [20])

\begin{tabular}{llll}
\hline Municipality & $\begin{array}{l}\text { Total number } \\
\text { of plant species }\end{array}$ & Plant family & $\begin{array}{l}\text { Number of } \\
\text { plant species }\end{array}$ \\
\hline Coyomeapan & 281 & Asteraceae & 26 \\
& & Solanaceae & 17 \\
& Rosaceae & 15 \\
& Fabaceae & 9 \\
Coxcatlán & 233 & Agavaceae & 8 \\
& Araceae & 15 \\
& Cactaceae & 14 \\
& Liliaceae & 13 \\
& Solanaceae & 12 \\
& & Crassulaceae & 10 \\
\hline
\end{tabular}

economic aspects configuring the role of the system in local people's subsistence.

The area comprised in this study is a relatively small portion of the great diversity of biocultural contexts of the Tehuacán Valley and it is far to be representative of the region. We reported information for only four of a total of 36 types of vegetation [45], and for one of eight indigenous ethnic groups of the region [16]. It is therefore possible to expect a high diversity of settings at the regional level yet to be studied. The method carried out allowed a relatively rapid diagnostic that could be implemented in short time for sampling the different biocultural conditions of the Tehuacán Valley, which would allow constructing strategies for regional biodiversity conservation and sustainable management. What is particularly relevant from our current study is the fact that the homegardens described are the expression of a current capacity for maintaining general diversity, and their important role for satisfying needs of local peoples.

Plant management involves important traditional ecological knowledge, practices, and technical experiences for designing any management plan. Most managed species were recorded in homegardens of CFZ, followed by those of TRFZ and TDFZ. Most species recorded are cultivated, followed by tolerated and enhanced plants. Most cultivated species are ornamental plants and edible

Table 8 Percentage of native plant species that are managed and used in different forms in the municipalities of Coyomeapan (this study) and San Rafael Coxcatlán, Puebla (according to Blanckaert et al. [20])

\begin{tabular}{|c|c|c|c|c|}
\hline Municipality & Management type & $\%$ & Use & $\%$ \\
\hline \multirow[t]{9}{*}{ Coyomeapan } & Cultivated & 63 & Ornamental & 49.2 \\
\hline & & & Edible & 42.2 \\
\hline & & & Medicinal & 9.8 \\
\hline & Protected & 12 & Ornamental & 28 \\
\hline & & & Edible & 44 \\
\hline & & & Medicinal & 20 \\
\hline & Tolerated & 25 & Ornamental & 17.5 \\
\hline & & & Edible & 14 \\
\hline & & & Medicinal & 36.8 \\
\hline \multirow[t]{9}{*}{ Coxcatlán } & Cultivated & 68 & Ornamental & 70 \\
\hline & & & Edible & 29.5 \\
\hline & & & Medicinal & 6.5 \\
\hline & Protected & 10 & Ornamental & 47.6 \\
\hline & & & Edible & 36.5 \\
\hline & & & Medicinal & 15.9 \\
\hline & Tolerated & 22 & Ornamental & 55.2 \\
\hline & & & Edible & 31 \\
\hline & & & Medicinal & 17.2 \\
\hline
\end{tabular}


species and only nearly $10 \%$ are medicinal plant; however most of the tolerated species are medicinal plants. Most studies on plant management have been centred in edible plants, but the results from this study suggest that studies on management and domestication should put more attention to ornamental and medicinal plants. Most enhanced or promoted plant species are edible and clearly this management type is directed to increase this benefit (Table 8). Although only $15 \%$ of all plant species recorded are commercialized, production in homegardens is continuous allowing monetary incomes throughout the year.

According with Altieri [27], traditional management systems may be adapted for increasing productivity and sustainability. For such purpose it is particularly relevant promoting conservation of diversity in agroecosystems as much as possible. Such purpose may increase the potential contribution of these systems to biodiversity conservation, food sufficiency, and ecological functions that favour higher resilience capacity and lower vulnerability to natural or socio-economic and cultural contingencies. Based on the information reported, it is possible to affirm that local homegardens are important reservoirs of biodiversity and that although local native biodiversity maintained within them is relatively lower than in other agroforestry systems, they may significantly contribute to its conservation at regional level. Such capacity should also be seen at landscape level. Considering that these systems may harbour endemic threatened species, they should be included in the strategies of biodiversity conservation and human wellbeing at regional level of the important biosphere reserve Tehuacán-Cuicatlán.

\section{Conclusions}

Homegardens studied in the municipality of Coyomeapan are reservoirs of high plant species diversity, nearly $34 \%$ of it being native to the Tehuacán Valle and nearly $16 \%$ to the local vegetation. The highest diversity was recorded in homegardens where the neighbouring forests had the least diversity, which suggests that management of homegardens aims at compensating scarcity of naturally available plant resources. Differently to other agroforestry systems of the area, cultivated species were markedly more abundant than plants under other management forms. Homegardens' composition is influenced by ecological conditions and social factors according the role of the system in local people's subsistence.

The information documented may support local programs for agroecological practices linked to dynamic conservation of biodiversity and culture. Homegardens may be important for local and regional strategies of protection of threatened species along with those of economic importance. Promoting interchange of local experiences about use and management techniques among rural communities, as well as diffusion of ecological and cultural information about the species managed could strongly support such a process. Academic institutions and NGOs might contribute with scientific and regional and national management experiences for making decisions at different scales.

\section{Competing interests}

The authors declare that they have no competing interests.

\section{Authors' contributions}

$\mathrm{CL}$ main author, involved in the study design, conducting of interview, field work, literature review and general data collection and systematization, wrote the first draft and concluded the final version this paper. AC main coordinator-supervisor of the research project; contributed with original data and the designing of all the researches providing the information for the current analysis; participated in fieldwork, systematization and analysis of data and reviewed several drafts of the manuscript. MV AIM and JB contributed to designing and following progress of the research and field work and data analyses. All authors read and approved the final manuscript.

\section{Authors' information}

$\mathrm{CL}$ Undergraduate student at the Centro de Investigaciones en Ecosistemas (CIECO), AC, full time researchers at CIECO, UNAM. AIM associate professor at the Escuela Nacional de Estudios Superiores, UNAM, MV and JB postgraduate student at the Centro de Investigaciones en Ecosistemas (CIECO), UNAM.

\section{Acknowledgements}

The authors thank the Centro de Investigaciones en Ecosistemas, Universidad Nacional Autónoma de México and Universidad Michacana de San Nicolás de Hidalgo for supporting the research. We specially thank people and local authorities of the communities studied, their generosity for sharing their knowledge and facilities for conducting the vegetation sampling. We also thank the Consejo Nacional de Ciencia y Tecnología (Project CB 2008-01103551), and the Programa de Apoyo a la Investigación e Innovación Tecnológica (PAPIIT, Projects IN205111-3 and IN209214) of the DGAPA, UNAM for financial support. MSc Edgar Pérez-Negrón provided fieldwork assistance, whereas Dr. Fernando Villaseñor and Guillermo Vázquez gave computer and statistical assistance and two anonymous reviewers that provided valuable suggestions and comments.

\section{Author details}

${ }^{1}$ Centro de Investigaciones en Ecosistemas, UNAM, Antigua Carretera a Pátzcuaro 8711, Col. San José de la Huerta Morelia, Michoacán 58190, México. ${ }^{2}$ Escuela Nacional de Estudios Superiores, UNAM, Antigua Carretera a Pátzcuaro 8711, Col. San José de la Huerta Morelia, Michoacán 58190, México.

Received: 16 September 2013 Accepted: 28 October 2013 Published: 6 November 2013

\section{References}

1. Kumar BM, Nair PKR: The enigma of tropical homegardens. Agrofor Syst 2004, 61:135-152.

2. Budowski G: Agroforistería: una diciplina basada en el conocimiento tradicional. Rev Forestal Centroamericana 1993, 2:14-18.

3. Lok R: El huerto casero tropical tradicional en América Central. In Lok R (ed) Huertos Caseros Tradicionales de América Central: Características, Beneficios e Importancia, Desde un Enfoque Multidisciplinario. Turrialba, Costa Rica: Centro Agronómico Tropical de Investigación y Enseñanza (CATIE); 1998:7-28.

4. Nair PKR, Kumar BM: Introduction. In Tropical Homegardens: A Time-Tested Example of Sustainable Agroforestry. Edited by Kumar BM, Nair PKR. Dordrecht, The Netherlands: Springer; 2006:1-10.

5. Perfecto I, Vandermeer J: Biodiversity conservation in tropical agroecosystems: a new conservation paradigm. N.Y. Acad Sci 2008, 1134:173-200.

6. Blancas J, Casas A, Rangel-Landa S, et al: Plant management in the Tehuacán-Cuicatlán Valley. Econ Bot 2010, 64:287-302. 
7. Moreno-Calles A, Casas A, Blancas J, et al: Agroforestry systems and biodiversity conservation in arid zones: the case of the Tehuacán Valley, Central México. Agrofor Syst 2010, 80:315-331.

8. Parra F, Blancas J, Casas A: Landscape management and domestication of Stenocereus pruinosus (Cactaceae) in the Tehuacán Valley: human guided selection and gene flow. J Ethnobiol Ethnomed 2012, 8:32.

9. Blancas J, Casas A, Pérez-Salicrup D, Caballero J, Vega E: Ecological and sociocultural factors influencing plant management in Náhuatl communities of the Tehuacán Valley, Mexico. J Ethnobiol Ethnomed 2013, 9:39.

10. Otero-Arnaiz A, Casas A, Hamrick J, Cruse-Sanders J: Genetic variation and evolution of Polaskia chichipe (Cactaceae) under domestication in the Tehuacán Valley, central Mexico. Mol Ecol 2005, 14:1603-1611.

11. Casas A, Cruse J, Otero-Arnaiz A, Valiente-Banuet A: Maintenance of phenotypic diversity of Stenocereus stellatus (Cactaceae) by indigenous people in central México. Biodivers Conserv 2006, 15:879-898.

12. Parra F, Casas A, Peñaloza-Ramírez JM, et al: Evolution under domestication: ongoing artificial selection and divergence of wild and managed Stenocereus pruinosus (Cactaceae) populations in the Tehuacán Valley, Mexico. Ann Bot 2010, 106:483-496.

13. Caballero J: The Maya homegardens of the Yucatán peninsula: past, present and future. Etnoecológica 1992, 1:35-54.

14. Casas A, Vázquez MC, Viveros $\mathrm{J}$, Caballero J: Plant management among the Nahua and the Mixtec from the Balsas River Basin: and ethnobotanical approach to the study of plant domestication. Hum Ecol 1996, 24:455-478.

15. Casas A, Caballero J, Valiente-Banuet A, Soriano JA, Dávila P: Morphological variation and the process of domestication of Stenocereus stellatus (Cactaceae) in Central Mexico. Am J Bot 1999, 86:522-533.

16. Casas A, Valiente-Banuet A, Viveros $J$, et al: Plant resources of the Tehuacán Valley, Mexico. Econ Bot 2001, 55:129-166.

17. Casas A, Otero-Arnaiz A, Pérez-Negrón E, et al: In situ management and domestication of plants in Mesoamerica. Ann Bot 2007, 100:1101-1115.

18. Casas A, Rangel-Landa S, Torres-García I, et al: In situ management and conservation of plant resources in the Tehuacán-Cuicatlán Valley, Mexico: an ethnobotanical and ecological approach. In Current Topics in Ethnobotany. Edited by Albuquerque UP, Alves-Ramos M. Kerala, India: Research Signpost; 2008:1-25.

19. Cruse-Sanders J, Friar E, Parker K, et al: Managing diversity: domestication and gene flow in Stenocereus stellatus Riccob. in Mexico. Ecol and Evol 2013, 3:1340-1355.

20. Blanckaert I, Swennen RL, Paredes-Flores M, et al: Floristic composition, plant uses and management practices in homegardens of San Rafael Coxcatlán, Valley of Tehuacán-Cuicatlán, Mexico. J Arid Environ 2004, 57:39-62.

21. Montagnini F: Homegardens of Mesoamerica: biodiversity, food security, and nutrient management. In Tropical Homegardens: A Time Tested Example of Sustainable Agroforestry. Edited by Kumar BM, Nair PKR. The Netherlands: Springer; 2006:61-84.

22. Pulido MT, Pagaza-Calderón M, Martínez-Ballesté A, et al: Home gardens as an alternative for sustainability: challenges and perspectives in Latin America. In Current Topics in Ethnobotany. Edited by Albuquerque UP, Alves-Ramos M. Kerala, India: Research Signpost; 2008:55-79.

23. Casas A, Caballero J, Mapes C, Zárate S: Manejo de la vegetación, domesticación de plantas y origen de la agricultura en Mesoamérica. Bol Soc Bot Méx 1997, 61:31-47.

24. Toledo VM, Barrera-Bassols N: La Memoria Biocultural: La Importancia Ecológica de las Sabidurías Tradicionales. Barcelona, Spain: Ed. Icaria; 2008.

25. Boege E: El Patrimonio Biocultural de los Pueblos Indígenas de México: Hacia la Conservación in Situ de la Biodiversidad y Agrobiodiversidad de los Territorios Indígenas. Instituto Nacional de Antropología e. México: Historia; 2008.

26. Van der Wal H, Bongers F: Biosocial and bionumerical diversity of variously sized homegardens in Tabasco, México. Agrofor Syst 2013, 87:93-107.

27. Altieri MA: Agroecology, small farms and food sovereignty. Mon Rev 2009, 61:102-113.

28. Godfray $\mathrm{CH}$, Beddington JR, Crute $\mathrm{R}$, et al: Food security: the challenge of feeding 9 billion people. Science 2010, 327:812-818.

29. Moreno-Calles A, Casas A, García-Frapolli E: Traditional agroforestry systems of multi-crop "milpa" and "chichipera" cactus forest in the arid Tehuacán Valley, Mexico: their management and role in people's subsistence. Agrofor Syst 2012, 84:207-226.
30. Hernández-Xolocotzi E: Aspects of plant domestication in Mexico: a personal view. In Biological Diversity of Mexico. Edited by Ramamoorthy TP, Bye R, Lot A, Fa J. Oxford: Oxford University Press; 1993:733-753.

31. Toledo VM: Indigenous Peoples and Biodiversity. In Encyclopedia of Biodiversity. Edited by Levins S, et al. New York: Academic Press; 2000.

32. Berkes F, Folke C, Gadgil M: Traditional ecological knowledge, biodiversity, resilience and sustainability. In Biodiversity Conservation. Edited by Perrings. The Netherlands: Kluwer Academic Publishers; 1995:281-299.

33. Camou-Guerrero A, Reyes-García V, Martínez-Ramos M, Casas A: Knowledge and use value of plant species in a Raramuri community: a gender perspective. Hum Ecol 2008, 36:259-272.

34. Dávila P, Arizmendi MC, Valiente-Banuet A, et al: Biological diversity in the Tehuacan-Cuicatlan Valley, Mexico. Biodivers Conserv 2002, 11:421-442.

35. Mangel M, Hofman RJ, Norse EA, Twiss JR: Sustainability and ecological research. Ecol Appl 1993, 3:573-575.

36. Goodland R: The concept of enviromental sustaninability. Annu Rev Ecol Syst 1995, 26:1

37. Torquebiau E: Are tropical agroforestry homegardens sustainable? Agr Ecosyst Environ 1992, 41:189-207.

38. Torquebiau E, Penot E: Ecology Versus Economics in Tropical Multistrata Agroforests. In Tropical Homegardens: A Time Tested Example of Sustainable Agroforestry. Edited by Kumar BM, Nair PKR. The Netherlands: Springer; 2006:269-282.

39. Lira R, Casas A, Rosas-López R, et al: Traditional knowledge and useful plant richness in the Tehuacán-Cuicatlán Valley, Mexico. Econ Bot 2009, 63:271-287.

40. Gliessman S: Agroecología: Procesos Ecológicos en Agricultura Sostenible. Turrialba, Costa Rica: LITOCAT; 2002

41. Vivar D: Determinación de la Sustentabilidad en el Manejo del Quiotillal en el Valle de Tehuacán-Cuicatlán. México. Bachellor Thesis. Mexico: Facultad de Ciencias, Universidad Nacional Autónoma de México; 2004.

42. Martin GJ: Ethnobotany: A Methods Manual. Cambridge, UK: Chapman \& Hall; 1995.

43. Toledo VM, Ortiz-Espejel MB, Cortés ME, et al: The multiple use of tropical forests by indigenous peoples in Mexico: a case of adaptive management Conserv Ecol 2003, 7(3):9

44. Barrera A: Sobre la unidad de habitación tradicional campesina y el manejo de recursos bióticos en el área Maya Yucatanense. Biotica 1980, 5:115-119.

45. Valiente-Banuet A, Casas A, Dávila P, Arizmendi MC, Solís L, Treviño J, Rangel $S$ : La Vegetación del Valle de Tehuacán-Cuicatlán. CONABIO, Fundación Cuicatlán, México: UNAM; 2009.

doi:10.1186/1746-4269-9-74

Cite this article as: Larios et al:: Plant management and biodiversity conservation in Náhuatl homegardens of the Tehuacán Valley, Mexico. Journal of Ethnobiology and Ethnomedicine 2013 9:74.

\section{Submit your next manuscript to BioMed Central and take full advantage of:}

- Convenient online submission

- Thorough peer review

- No space constraints or color figure charges

- Immediate publication on acceptance

- Inclusion in PubMed, CAS, Scopus and Google Scholar

- Research which is freely available for redistribution 